\title{
Phytochemical and Antioxidant Diversity in Fruits of Currant (Ribes spp.)
}

\author{
Nilda ERSOY', Muhammed KUPE ${ }^{2}$, Muttalip GUNDOGDU ${ }^{3}$, \\ ${\text { Gulce ILHAN }{ }^{2} \text {, Sezai ERCISLI* }}^{2 *}$ \\ I'Akdeniz University, Faculty of Agriculture,Department of Horticulture Antalya, Turkey; nildaersoy@gmail.com \\ ${ }^{2}$ Ataturk University, Faculty of Agriculture, Department of Horticulture, Erzurum, Turkey; muhammed.kupe@atauni.edu.tr; \\ gulce.ilhan@atauni.edu.tr; sercisli@gmail.com (*0rrespondingauthor) \\ ${ }^{3}$ Abant Izzet Baysal University, Faculty of Agriculture and Natural Sciences, Department of Horticulture, Bolu, Turkey; \\ gundogdumuttalip@gmail.com
}

\begin{abstract}
Currant successfully grown in a wide area in Turkey due to its environmental plasticity. The aim of this study is to determine variations in phytochemical contents and antioxidant capacity from certain currant cultivars and genotypes commercially grown in Turkey. Fruit samples taken from two red currant cultivars ('Red Lake', 'Rovada') and four black ('S. Nigrum', 'Tokat 2', 'Tokat 3' and 'Tokat 4') and the genotype 1310 (red currant) were subjected to analysis for phenolic compounds (protocatechuic, vanillic acid, ellagic acid, rutin, quercetin, gallic acid, catechin, chlorogenic acid, caffeic acid, syringic acid, p-coumaric acid, o-coumaric acid, phloridzin and ferulic acid), organic acids (citric acid, tartaric acid, malic acid, succinic acid, and fumaric acid), vitamin $\mathrm{C}$, antioxidant capacity (Trolox equivalent antioxidant capacity [TEAC] assay) and sugars (glucose, fructose and sucrose). Results showed that phytochemical contents and antioxidant capacities statistically varied among currant cultivars and genotype $(\mathrm{p}<0.05)$. Caffeic acid was determined only in the genotype 1301. Ellagic acid $(1.680 \mathrm{mg} / 100 \mathrm{~g})$, gallic acid $(2.022 \mathrm{mg} / 100 \mathrm{~g})$, rutin $(4.649 \mathrm{mg} / 100 \mathrm{~g})$, catechin $(8.005 \mathrm{mg} / 100 \mathrm{~g})$ and chlorogenic acid $(2.721 \mathrm{mg} / 100 \mathrm{~g})$ were found the highest values in 'Tokat 3', 'Red Lake, 'Tokat 3', 1310 and 'S. Nigrum', respectively. Citric acid, fumaric acid, and malic acid were dominant among organic acids for all cultivars and the genotype 1310. Contents of glucose and fructose among sugars were measured to be higher than content of sucrose for all cultivars and the genotype. The highest antioxidant capacity was detected in cultivar of 'Rovada' and the genotype 1310.
\end{abstract}

Keywords: black currant; phenolic compounds; phytochemicals; red currant

\section{Introduction}

Fruits are diets high and widely recommended for their health-promoting properties. They historically held a place in dietary guidance because of their high concentrations of vitamins, especially vitamins $\mathrm{C}$ and $\mathrm{A}$; minerals, especially electrolytes; and more recently phytochemicals. Fruits are also important source of antioxidant substances and dietary fiber (Kamiloglu et al., 2009; Tosun et al., 2009; Ercisli et al., 2012; Yazici and Sahin, 2016; Zorenc et al., 2016).

Currant not only includes several vitamins and nutritional minerals but also has appetizing, digestive, diuretic, anti-inflammatory, and anti-rheumatic properties. Owing to their unique taste, color, and odor, currants are used in many foods such as fruit juice, jam, syrup, marmalade, jelly, candy, cream-cake, ice cream, and dairy products. Like the other berries, currant can support a healthy life by having a protective effect against chronic disorders, cancer, and cardiac diseases by virtue of their phytochemicals (Maatta et al., 2010; Milivojevic et al., 2012; Mikulic-Petkovsek et al., 2015; Mattila et al., 2016; Mikulic-Petkovsek et al., 2016). Furthermore, currant having numerous phenolics and high antioxidant activity, particularly black currant, has become a crucial tool for functional food industry (Anttonen and Karjalainen, 2006).

Phenolics, which are one of the most significant phytochemical groups commonly forming in plants, are substantially important from physiological and morphological aspects. These compounds play a critical part for development and reproduction and ensuring protection against pathogens and predators as well as contributing to formation of color and sensory properties in fruits and vegetables (Mikulic-Petkovsek et al., 2016). Positive effects 
382

of berry fruits on health are also associated with their phenolic compounds. Beneficial effects provided by these phenolic compounds are based on their antioxidant activity (Heim et al., 2002). Berry fruits rich sources of phenolic compound containing anthocyanins, flavonols, ellagitannins, hydroxybenzoic acid, hydroxycinnamic acid, and proanthocyanidins (Maatta et al., 2001; Wu et al., 2004).

Anthocyanin deficiency in colorless fruits (green and white) was associated with the increasing levels of phenolic acids. Anthocyanins were dominant in black and red currants and also proanthocyanidins and phenolic acids were more dominant in green and white currants (Maatta $e t$ al., 2001). Studies indicated that numerous berry fruit species are the source of phenolic compound and value of these fruit species has increased with the use of them as raw material in several products and understanding their benefits on human health (Haslam, 1996; Parr and Bolwell, 2000; Maatta-Riihinen et al., 2004). Phenolic compounds were reported decreasing free radicals, preventing cancer, strengthening immune system and inhibiting formation of tumor (Zhishen et al., 1999; Bermudez-Soto and TomasBarberan, 2004). Fruit juice mixture containing some berry fruits also including black currant with high amounts of phenolic compounds particularly anthocyanins (Moyer $e t$ al., 2002) was reported to lead health protecting effects by both being consumed and used as functional food due to anthocyanins and ascorbic acid (Netzel et al., 2002). It was stated that the growing region and weather conditions had an effect on phenolic compound in fruits and differences occurred between cultivars (Dogan et al., 2014; Alp et al., 2016). All cultivars of black currant growing in regions with high altitude were also determined to have lower contents of total flavonol, total anthocyanin, and total phenolic compound compared to those growing in lowlands. In addition temperature and light exposure caused major changes on composition of phenolic compound (Zheng et al., 2012). It was observed that cultivation systems also had an effect on phenolic content and antioxidant capacity and fruits of organically grown currant had higher total phenolic content especially anthocyanins and higher antioxidant activity compared to conventionally grown ones (Anttonen and Karjalainen, 2006; Wojdylo et al., 2013). Eyduran and Agaoglu (2007) stated that the most appropriate currant cultivar for climate conditions of Ankara was 'Red Lake'. In a two-year study examining four black currant cultivars ('Titania', 'Triton', 'Tsema' and 'Cacanska Crna') and three red currant cultivars ('Junifer', 'Rolan' and 'Stanza'); anthocyanins were measured to be more dominant in black cultivars compared to red ones. In addition, even though sugars and organic acids were determined to have similar amounts in both species of Ribes, vitamin C was three times higher in black currants (Milivojevic et al., 2012).

In this study, some red and black currant cultivars growing in Turkey and the genotype 1310 (red currant), which was determined as a result of selection studies, were examined and their phytochemical contents were identified. The fact that the study determines especially anticarcinogenic phenolic compounds, organic acids, and antioxidant capacities of currant fruits that are essential for human health and are among important quality criteria reveals currency of the study and also the genotype 1310 presenting significant results is also thought to make contributions to breeding studies.

\section{Materials and Methods}

\section{Plantmaterial}

In this study, four black currant cultivars ('Tokat 2', 'Tokat 3', 'Tokat 4' and 'S. Nigrum'), two red currant cultivars ('Red Lake' and 'Rovada') and one red currant genotype (1310 type) were used. The plants were planted in $1 \times 1.5 \mathrm{~m}$ intervals in Malatya province in Turkey and the drip irrigation was used.

The fruits were harvested in the last week of June. Harvest was made in periods when fruits of examined cultivars and genotypes completely ripe. Fruit sample of approximately $500 \mathrm{~g}$ was taken from each cultivar and genotype. Fruit samples collected homogenously were stored at $-80{ }^{\circ} \mathrm{C}$ until their laboratory analyses were performed.

\section{Analysis of phenolic acids}

Protocatechuic, ellagic acid, gallic acid, catechin, chlorogenic acid, caffeic acid, p-coumaric, o-coumaric, vanillic, rutin, syringic acid, quercetin, phloridzin, and ferulic acids were detected among phenolic acids in currant fruits in accordance with the modified method of Rodriguez-Delgado et al. (2001). Fruit extracts were mixed with distilled water at the ratio of 1:1. The mixture was centrifuged for $15 \mathrm{~min}$ at $15000 \mathrm{rpm}$. Supernatants were filtrated with coarse filter paper and twice with $0.45 \mu \mathrm{m}$ membrane filter (Millipore Millex-HV Hydrophilic PVDF, Millipore, USA), and injected into an HPLC (Agilent. USA). Chromatographic separation was performed with a $250 \times 4.6 \mathrm{~mm}, 4 \mu \mathrm{m}$ ODS column (HiChrom, USA). Solvent A methanol: acetic acid: water (10:2:28) and Solvent B methanol: acetic acid: water (90:2:8) were used as the mobile phase. Spectral measurements were made at 254 and $280 \mathrm{~nm}$, and flow rate and injection volume were adjusted to $1 \mathrm{~mL} / \mathrm{min}$ and $20 \mu \mathrm{L}$, respectively.

\section{Analysis of organic acids}

Succinic acid, citric acid, malic acid, fumaric acid and tartaric acid composition of the currant berries were identified by Bevilacqua and Califano (1989). Juice extracts were obtained by mashing the berries in cheesecloth, then the samples were stored at $-20^{\circ} \mathrm{C}$ until they were analyzed. 5 $\mathrm{mL}$ of each sample was mixed with $20 \mathrm{ml}$ of $0.009 \mathrm{~N} \mathrm{H}_{2} \mathrm{SO}_{4}$ (Heidolph Silent Crusher M, Germany), and then homogenized for $1 \mathrm{~h}$ with a shaker (Heidolph Unimax 1010 , Germany). The mixture was centrifuged for $15 \mathrm{~min}$ at $15000 \mathrm{rpm}$, and supernatants were filtrated twice with 0.45 $\mu \mathrm{m}$ membrane filter after filtration with coarse filter (Millipore Millex-HV Hydrophilic PVDF, Millipore, USA) and run through a SEP-PAK C18 cartridge. Organic acid readings were performed with HPLC using Aminex column (HPX $-87 \mathrm{H}, 300 \mathrm{~mm} \times 7.8 \mathrm{~mm}$, Bio-Rad Laboratories, Richmond, CA, USA) at 214 and $280 \mathrm{~nm}$ wavelengths, using Agilent packaged software (Agilent, USA). 


\section{Analysis of Vitamin $C$}

Vitamin $\mathrm{C}$ content was detected based on modified HPLC procedure suggested by Cemeroglu (2007). $5 \mathrm{ml}$ of the fruit extracts was supplemented with $2.5 \%(\mathrm{w} / \mathrm{v})$ metaphosphoric acid (Sigma, M6285, 33.5\%), then centrifuged at $6500 \mathrm{rpm}$ for $10 \mathrm{~min}$ at $4{ }^{\circ} \mathrm{C}$. $0.5 \mathrm{ml}$ of the mixture was brought to final volume of $10 \mathrm{ml}$ with $2.5 \%$ $(\mathrm{w} / \mathrm{v})$ metaphosphoric acid. Supernatants were filtered with $0.45 \mu \mathrm{m}$ PTFE syringe filter (Phenomenex, UK). C18 column (Phenomenex Luna C18, $250^{\circ} 4.60 \mathrm{~mm}, 5 \mu$ ) was used for identification of ascorbic acid at $25^{\circ} \mathrm{C}$. Ultra distilled water with $1 \mathrm{ml} / \mathrm{min}$ flow rate and $\mathrm{pH}$ of 2.2 (acidified with $\mathrm{H}_{2} \mathrm{SO}_{4}$ ) was used as a mobile phase. Spectral measurements were made at $254 \mathrm{~nm}$ wavelength by using DAD detector. Different standards of L-ascorbic acid (SigmaA5960) (50, 100, 500, 1000, and $2000 \mathrm{ppm}$ ) were used for quantification of ascorbic acid readings.

\section{Determination of Trolox Equivalent Antioxidant Capacity (TEAC)}

Trolox equivalent antioxidant capacity (TEAC) was determined with ABTS by dissolving in acetate buffer using potassium persulphate (Ozgen et al., 2006). For longer stability, the mixture was diluted with $20 \mathrm{mM}$ sodium acetate buffer in acidic $\mathrm{pH}$ of 4.5 , and read at $734 \mathrm{~nm}$ wavelength, $0.700 \pm 0.01$. For spectrometric assay, $3 \mathrm{ml}$ ABTS+ was mixed with $20 \mu \mathrm{l}$ fruit extract sample and incubated for $10 \mathrm{~min}$ at $734 \mathrm{~nm}$ wavelength for absorbance detection.

\section{Sugar analysis}

The modified method of Melgarejo et al. (2000) was used for sugar (glucose, fructose, and sucrose) analyses. $5 \mathrm{ml}$ of fruit extracts was centrifuged at $12000 \mathrm{rpm}$ for $2 \mathrm{~min}$ at $4^{\circ} \mathrm{C}$. Supernatants were passed by SEP-PAK C18 cartridge. HPLC readings were made with $\mu$ Bondapak-NH 2 column using $85 \%$ acetonitrile as liquid phase with refractive index detector (IR). Fructose and glucose standards were used for sugar calculations.

\section{Statistical analyses}

Three replicates including 30 fruits per replicate were carried out. Descriptive statistics of phenolic compounds, organic acids, sugars, vitamin $\mathrm{C}$, and antioxidant capacity extracted from cultivars and genotype were represented as mean \pm SE. Experimental data were evaluated by using analysis of variance ANOVA and significant differences between the means of three replicates $(p<0.005)$ were determined by using Duncan's multiple range test in the SPSS 20 for Windows.

\section{Results and Discussion}

\section{Phenolic acids}

In this study, protocatechuic, vanillic acid, ellagic acid, rutin, quercetin, gallic acid, catechin, chlorogenic acid, caffeic acid, syringic acid, p-coumaric acid, o-coumaric acid, phloridzin, and ferulic acid contents among phenolic compounds varied in all cultivars and genotype (Table 1). Protocatechuic acid content was measured to be the highest in 'S. Nigrum' cultivar $(1.422 \mathrm{mg} / 100 \mathrm{~g})$ and the lowest in genotype $1310(0.238 \mathrm{mg} / 100 \mathrm{~g})$. The amount of vanillic acid in currants ranged between $0.390 \mathrm{mg} / 100 \mathrm{~g}$ and 0.078 $\mathrm{mg} / 100 \mathrm{~g}$. The highest ellagic acid content was determined as $1.680 \mathrm{mg} / 100 \mathrm{~g}$ in 'Tokat 3' cultivar, whereas the lowest ellagic acid content was determined as $0.797 \mathrm{mg} / 100 \mathrm{~g}$ in 'Tokat 2'. The rutin content was measured as the highest value $(4.649 \mathrm{mg} / 100 \mathrm{~g})$ in 'Tokat 3' cultivar, the lowest value was found as $1.521 \mathrm{~g} / 100 \mathrm{~g}$ in 'Red Lake' cultivar. The highest quercetin content was $0.850 \mathrm{mg} / 100 \mathrm{~g}$ in 'Rovada' cultivar. Gallic acid content was measured between 2.022 $\mathrm{mg} / 100 \mathrm{~g}$ and $1.011 \mathrm{mg} / 100 \mathrm{~g}$ amongst the cultivars and genotypes. The highest catechin level was $8.005 \mathrm{mg} / 100 \mathrm{~g}$ in genotype 1310; whereas, the lowest level was $1.920 \mathrm{mg} / 100$ $\mathrm{g}$ in 'Tokat 4' cultivar (Table 1). The highest chlorogenic acid content was $2.721 \mathrm{mg} / 100 \mathrm{~g}$ in 'S. Nigrum' cultivar. Caffeic acid content was determined as $0.198 \mathrm{mg} / 100 \mathrm{~g}$ only in genotype 1310 . While highest Syringic acid content was obtained from 'Red Lake' and 'Tokat 3' cultivars (0.149 and $0.146 \mathrm{mg} / 100 \mathrm{~g}$, respectively), the lowest value was $0.073 \mathrm{mg} / 100 \mathrm{~g}$ and determined in 'Rovada' cultivar. The highest p-coumaric acid content was $0.167 \mathrm{mg} / 100 \mathrm{~g}$ and determined in 'Tokat 3' cultivar. The highest o-coumaric acid content was found in 'Rovada' cultivar at the level of $0.177 \mathrm{mg} / 100 \mathrm{~g}$. The highest phloridzin content was detected as $0.662 \mathrm{mg} / 100 \mathrm{~g}$ in fruits from 'Rovada' cultivar. While the genotype 1310 yielded the best result with 0.605 $\mathrm{mg} / 100 \mathrm{~g}$ in terms of ferulic acid content, ferulic acid level was determined between $0.153 \mathrm{mg} / 100 \mathrm{~g}$ and 0.605 $\mathrm{mg} / 100 \mathrm{~g}$ among the samples (Table 2).

Hakkinen et al. (1999) used 19 berry fruits and determined that quercetin, p-coumaric acid, caffeic acid,

Table 1. Protocatechuic acid, vanillic acid, ellagic acid, rutin, quercetin, gallic acid, and catechin contents (mg/100 g) of currant cultivars and genotype

\begin{tabular}{|c|c|c|c|c|c|c|c|}
\hline $\begin{array}{l}\text { Cultivars and } \\
\text { genotype }\end{array}$ & $\begin{array}{c}\text { Protocatechuic } \\
\text { acid }\end{array}$ & Vanillic acid & Ellagic acid & Rutin & Quercetin & Gallic acid & Catechin \\
\hline Red Lake & $0.349 \pm 0.001 \mathrm{~d}$ & ND & $0.950 \pm 0.128 \mathrm{c}$ & $1.521 \pm 0.015 \mathrm{f}$ & $0.635 \pm 0.006 b$ & $2.022 \pm 0.008 \mathrm{a}$ & $6.258 \pm 0.232 b$ \\
\hline Rovada & $0.723 \pm 0.007 \mathrm{c}$ & ND & $0.910 \pm 0.197 \mathrm{c}$ & $2.073 \pm 0.008 \mathrm{~d}$ & $0.850 \pm 0.003 \mathrm{a}$ & $1.470 \pm 0.010 \mathrm{~b}$ & $3.881 \pm 0.068 \mathrm{c}$ \\
\hline S. Nigrum & $1.422 \pm 0.008 \mathrm{a}$ & ND & $0.934 \pm 0.030 c$ & $2.837 \pm 0.011 \mathrm{c}$ & $0.124 \pm 0.001 \mathrm{f}$ & $0.309 \pm 0.008 \mathrm{e}$ & $3.548 \pm 0.032 \mathrm{c}$ \\
\hline Tokat 2 & $0.831 \pm 0.009 \mathrm{~b}$ & $0.078 \pm 0.002 \mathrm{c}$ & $0.797 \pm 0.115 \mathrm{c}$ & $3.221 \pm 0.011 b$ & $0.122 \pm 0.003 \mathrm{f}$ & $0.681 \pm 0.009 \mathrm{~d}$ & $3.456 \pm 0.036 \mathrm{c}$ \\
\hline Tokat 3 & $0.860 \pm 0.006 \mathrm{~b}$ & $0.390 \pm 0.009 a$ & $1.680 \pm 0.091 \mathrm{a}$ & $4.649 \pm 0.007 a$ & $0.147 \pm 0.002 \mathrm{e}$ & $1.011 \pm 0.009 c$ & $2.709 \pm 0.033 \mathrm{~d}$ \\
\hline Tokat 4 & $0.851 \pm 0.049 \mathrm{~b}$ & ND & $1.301 \pm 0.033 \mathrm{~b}$ & $1.829 \pm 0.013 \mathrm{e}$ & $0.159 \pm 0.004 \mathrm{~d}$ & $0.136 \pm 0.004 \mathrm{~g}$ & $1.920 \pm 0.025 \mathrm{e}$ \\
\hline 1310 & $0.238 \pm 0.004 \mathrm{e}$ & $0.173 \pm 0.005 b$ & $0.899 \pm 0.011 \mathrm{c}$ & $2.841 \pm 0.007 \mathrm{c}$ & $0.527 \pm 0.008 c$ & $0.201 \pm 0.002 \mathrm{f}$ & $8.005 \pm 0.600 a$ \\
\hline
\end{tabular}

${ }^{* *}$ : Difference between means represented with the different letter in the same column is significant at 0.05 level. ND: Not detected. 
Table 2. Chlorogenic acid, caffeic acid, syringic acid, p coumaric, o coumaric, phloridzin, and ferulic acid contents (mg/100 g) of currant cultivars and genotype

\begin{tabular}{|c|c|c|c|c|c|c|c|}
\hline $\begin{array}{l}\text { Cultivars and } \\
\text { genotype }\end{array}$ & Chlorogenic acid & Caffeic acid & Syringic acid & $p$ Coumaric & $o$ Coumaric & Phloridzin & Ferulic acid \\
\hline Red Lake & $1.705 \pm 0.009 \mathrm{~d}$ & ND & $0.149 \pm 0.001 \mathrm{a}$ & $0.080 \pm 0.001 \mathrm{e}$ & $0.068 \pm 0.001 \mathrm{e}$ & $0.349 \pm 0.002 \mathrm{c}$ & $0.234 \pm 0.002 b$ \\
\hline Rovada & $1.544 \pm 0.008 \mathrm{e}$ & ND & $0.073 \pm 0.001 \mathrm{~d}$ & $0.071 \pm 0.004 \mathrm{f}$ & $0.177 \pm 0.001 \mathrm{a}$ & $0.662 \pm 0.020 \mathrm{a}$ & $0.153 \pm 0.005 \mathrm{e}$ \\
\hline S. Nigrum & $2.721 \pm 0.057 \mathrm{a}$ & ND & $0.119 \pm 0.004 \mathrm{c}$ & $0.151 \pm 0.004 \mathrm{~b}$ & $0.065 \pm 0.001 \mathrm{ef}$ & $0.456 \pm 0.010 \mathrm{~b}$ & $0.199 \pm 0.001 \mathrm{c}$ \\
\hline Tokat 2 & $2.372 \pm 0.011 b$ & ND & $0.132 \pm 0.002 b$ & $0.149 \pm 0.000 \mathrm{~b}$ & $0.098 \pm 0.001 \mathrm{~d}$ & $0.269 \pm 0.009 \mathrm{e}$ & $0.175 \pm 0.001 \mathrm{~d}$ \\
\hline Tokat 3 & $0.798 \pm 0.003 \mathrm{f}$ & ND & $0.146 \pm 0.000 \mathrm{a}$ & $0.167 \pm 0.001 \mathrm{a}$ & $0.061 \pm 0.001 \mathrm{f}$ & $0.261 \pm 0.004 \mathrm{e}$ & $0.203 \pm 0.001 \mathrm{c}$ \\
\hline Tokat 4 & $1.850 \pm 0.006 \mathrm{c}$ & ND & $0.122 \pm 0.003 \mathrm{c}$ & $0.128 \pm 0.001 \mathrm{~d}$ & $0.162 \pm 0.004 b$ & $0.207 \pm 0.003 \mathrm{f}$ & $0.174 \pm 0.002 \mathrm{~d}$ \\
\hline 1310 & $0.394 \pm 0.008 \mathrm{~g}$ & $0.198 \pm 0.001 \mathrm{a}$ & $0.118 \pm 0.004 \mathrm{c}$ & $0.142 \pm 0.002 c$ & $0.110 \pm 0.001 \mathrm{c}$ & $0.320 \pm 0.001 \mathrm{~d}$ & $0.605 \pm 0.005 a$ \\
\hline
\end{tabular}

${ }^{*}$ : Difference between means represented with the different letter in the same column is significant at 0.05 level. ND: Not detected.

ferulic acid and ellagic acid contents in currant (black, red, white, and green) samples were in the range of 10.1-39.6\%, 12.1-41.2\%, $\quad 16.1-34.0 \%, \quad 3.1-5.4 \%$, and $2.3-8.2 \%$; respectively. Maatta-Riihinen et al. (2004) measured pcoumaric acid content as $39,60,11$, and $31 \mathrm{mg} / \mathrm{kg}$ respectively and quercetin content as 50,33, 4, and 12 $\mathrm{mg} / \mathrm{kg}$ respectively in black, green, red, and white currants. Borges et al. (2010) determined that the amount of chlorogenic acid contained by black and red currants among berry fruits were 80 and $89 \mathrm{nmol} / \mathrm{g}$, respectively. As a result of analyses made in fruits of 'Rovada' and 'Rosenthal' currant cultivars, it was found that rutin content was between $1.89-4.24 \mathrm{mg} / 100 \mathrm{~g}$ and $0.47-4.58 \mathrm{mg} / 100 \mathrm{~g}$ respectively, catechin content was $7.49 \mathrm{mg} / 100 \mathrm{~g}$ in 'Rosenthal' cultivar and between $0.77-5.07 \mathrm{mg} / 100 \mathrm{~g}$ in 'Rovada' cultivar, chlorogenic acid content was 0.79 $\mathrm{mg} / 100 \mathrm{~g}$ in 'Rosenthal' cultivar and $0.97 \mathrm{mg} / 100 \mathrm{~g}$ in 'Rovada' cultivar, p-coumaric acid content was $0.91 \mathrm{mg} / 100$ $\mathrm{g}$ in 'Rosenthal' cultivar and $0.97 \mathrm{mg} / 100 \mathrm{~g}$ for 'Rovada' cultivar, and ferulic acid content was $0.63 \mathrm{mg} / 100 \mathrm{~g}$ in 'Rosenthal' cultivar and $0.71 \mathrm{mg} / 100 \mathrm{~g}$ in 'Rovada' cultivar (Gavrilova et al. 2011).

\section{Organic acids}

Organic acids are phytochemicals flavoring fruits and being critical in terms of human health. Previous studies revealed that organic acids, particularly malic acid, citric acid, and tartaric acid had significant contributions to health in several aspects such as strengthening immune system, preventing formation of kidney stones, relieving mouth sores, reducing risk of toxic metal poisoning, protecting beauty of skin, and decreasing fibromyalgia symptoms (Abraham and Flechas, 1992; Penniston et al., 2007). In this study, there were differences between cultivars and genotype in terms of organic acid contents (Table 3). Citric acid, fumaric acid, and malic acid among organic acids were determined to have the highest value in all currant cultivars and genotype. These were followed by tartaric acid and succinic acid. While 'Rovada' cultivar had the best value with $20.20 \mathrm{~g} / \mathrm{kg}$ in citric acid content, the genotype 1310 gave the lowest value with $12.25 \mathrm{~g} / \mathrm{kg}$. The highest tartaric acid content was measured as $1.64 \mathrm{~g} / \mathrm{kg}$ in 'Rovada' cultivar. The genotype 1310 gave the highest value as $9.22 \mathrm{~g} / \mathrm{kg}$ in terms of malic acid content; whereas, 'Red Lake' cultivar had the lowest value as $1.24 \mathrm{~g} / \mathrm{kg}$. 'Tokat 2' cultivar was determined to have the highest succinic acid content $(2.08 \mathrm{~g} / \mathrm{kg})$. The highest fumaric acid content was determined in 'Tokat 3' cultivar (Table 3). Zheng et al. (2009) determined malic acid and citric acid contents of white, green, and red currants as 3.4-10.5 and 16.1-25.7 g/L, respectively. According to results of their two-year trial, Milivojevic et al. (2012) measured citric acid, malic acid and tartaric acid contents of black currants as $5.7-7.2 \mathrm{~g} / \mathrm{kg}, 1.9$ $5.1 \mathrm{~g} / \mathrm{kg}$ and $0.2-0.5 \mathrm{~g} / \mathrm{kg}$ respectively in the first year,; on the other hand, they determined citric acid, malic acid and tartaric acid contents of black currants as $9.3-11.7 \mathrm{~g} / \mathrm{kg}, 2.4-$ $7.3 \mathrm{~g} / \mathrm{kg}$ and $0.5-1.2 \mathrm{~g} / \mathrm{kg}$ respectively in the second year. In addition, citric acid, malic acid, and tartaric acid contents of red currants were determined between $5.8-9.8 \mathrm{~g} / \mathrm{kg}, 2.9-3.8$ $\mathrm{g} / \mathrm{kg}$ and $0.3-0.9 \mathrm{~g} / \mathrm{kg}$ respectively in the first year; whereas, citric acid, malic acid and tartaric acid contents of red currants were determined between $9.6-14.7 \mathrm{~g} / \mathrm{kg}, 2.6-5.8$ $\mathrm{g} / \mathrm{kg}$ and $0.3-0.4 \mathrm{~g} / \mathrm{kg}$ respectively in the second year. Organic acid contents may emerge at different levels due to genetic factors, cultural applications, climate conditions, and soil structure (Celik et al., 2007; Hegedus et al., 2010).

\section{Vitamin $C$}

Differences were observed between cultivars and genotype in terms of vitamin C content (Table 4). The highest vitamin $C$ content was measured as $126.51 \mathrm{mg} / 100$ $\mathrm{g}$ in 'Tokat 2' cultivar, the lowest value was obtained as $14.94 \mathrm{mg} / 100 \mathrm{~g}$ in genotype 1310. Zheng et al. (2009) measured vitamin $\mathrm{C}$ content as 0.22 and $1.07 \mathrm{~g} / \mathrm{L}$ in currants. Karacali (2012) stated that fruit species could be classified within three groups that are poor, moderate, and rich in vitamin $\mathrm{C}$ contents. In this regard, currant fruits are involved in the group rich in vitamin C contents. 'Tokat 2' cultivar from cultivars used in this study was determined to be rich in vitamin C with $126.51 \mathrm{mg} / 100 \mathrm{~g}$. Borges et al. (2010) measured vitamin C contents of black and red currants as 2328 and $313 \mathrm{nmol} / \mathrm{g}$. In the study conducted by Milivojevic et al. (2012) on black and red currants in 2008 and 2009; they determined that vitamin C content was between 147.8-202.3 and 117.8-175.0 mg/100 g for black currants and 35.2-45.8 mg/100 g for white currants, respectively. 
Table 3. Citric acid, tartaric acid, malic acid, succinic acid, and fumaric acid contents in currant cultivars and genotype

\begin{tabular}{llllll}
\hline $\begin{array}{l}\text { Cultivars and } \\
\text { genotype }\end{array}$ & Citric acid & Tartaric acid & Malic acid & Succinic acid & Fumaric acid \\
\hline Red Lake & $15.07 \pm 0.07 \mathrm{~d}$ & $0.95 \pm 0.03 \mathrm{c}$ & $1.24 \pm 0.04 \mathrm{~g}$ & $0.73 \pm 0.01 \mathrm{~d}$ & $7.19 \pm 0.07 \mathrm{f}$ \\
Rovada & $20.20 \pm 0.07 \mathrm{a}$ & $1.64 \pm 0.06 \mathrm{a}$ & $1.49 \pm 0.03 \mathrm{f}$ & $1.41 \pm 0.02 \mathrm{c}$ & $8.52 \pm 0.04 \mathrm{e}$ \\
S. Nigrum & $12.62 \pm 0.06 \mathrm{e}$ & $0.91 \pm 0.03 \mathrm{c}$ & $2.30 \pm 0.08 \mathrm{e}$ & $2.02 \pm 0.05 \mathrm{a}$ & $12.80 \pm 0.10 \mathrm{~b}$ \\
Tokat 2 & $16.13 \pm 0.13 \mathrm{~b}$ & $1.07 \pm 0.06 \mathrm{~b}$ & $4.11 \pm 0.06 \mathrm{~b}$ & $2.08 \pm 0.10 \mathrm{a}$ & $12.60 \pm 0.13 \mathrm{c}$ \\
Tokat 3 & $12.31 \pm 0.07 \mathrm{f}$ & $0.66 \pm 0.01 \mathrm{~d}$ & $3.24 \pm 0.06 \mathrm{~d}$ & $1.82 \pm 0.01 \mathrm{~b}$ & $14.60 \pm 0.06 \mathrm{a}$ \\
Tokat 4 & $15.86 \pm 0.05 \mathrm{c}$ & $0.74 \pm 0.02 \mathrm{~d}$ & $3.74 \pm 0.03 \mathrm{c}$ & $2.00 \pm 0.03 \mathrm{a}$ & $8.80 \pm 0.07 \mathrm{~d}$ \\
\hline 1310 & $12.25 \pm 0.04 \mathrm{f}$ & $0.65 \pm 0.02 \mathrm{~d}$ & $9.22 \pm 0.05 \mathrm{a}$ & $0.25 \pm 0.01 \mathrm{e}$ & $6.56 \pm 0.07 \mathrm{~g}$ \\
\hline *: Difference between means represented with the different letter in the same column is significant at 0.05 level. & & &
\end{tabular}

*: Difference between means represented with the different letter in the same column is significant at 0.05 level.

Table 4. Vitamin C, total antioxidant capacity (TEAC), and sugar contents in currant cultivars and genotype

\begin{tabular}{|c|c|c|c|c|c|}
\hline $\begin{array}{l}\text { Cultivars and } \\
\text { genotype }\end{array}$ & Vitamin C & TEAC & Glucose & Fructose & Sucrose \\
\hline Red Lake & $52.93 \pm 0.04 \mathrm{e}$ & $35.03 \pm 0.13 \mathrm{~d}$ & $31.18 \pm 0.10 \mathrm{~b}$ & $16.23 \pm 0.08 \mathrm{a}$ & $1.36 \pm 0.04 b$ \\
\hline Rovada & $46.62 \pm 0.11 \mathrm{f}$ & $41.29 \pm 0.75 \mathrm{a}$ & $24.37 \pm 0.27 \mathrm{~d}$ & $12.25 \pm 0.11 \mathrm{c}$ & $1.03 \pm 0.02 \mathrm{~d}$ \\
\hline S. Nigrum & $99.47 \pm 0.24 \mathrm{~d}$ & $39.11 \pm 0.10 \mathrm{~b}$ & $34.23 \pm 0.08 \mathrm{a}$ & $15.19 \pm 0.08 \mathrm{~b}$ & $2.21 \pm 0.04 \mathrm{a}$ \\
\hline Tokat 2 & $126.51 \pm 1.02 \mathrm{a}$ & $33.11 \pm 0.06 \mathrm{e}$ & $20.99 \pm 0.30 \mathrm{e}$ & $11.23 \pm 0.16 \mathrm{~d}$ & $1.14 \pm 0.04 \mathrm{c}$ \\
\hline Tokat 3 & $108.76 \pm 0.34 b$ & $38.20 \pm 0.92 c$ & $19.32 \pm 0.19 \mathrm{f}$ & $11.20 \pm 0.14 \mathrm{~d}$ & $0.96 \pm 0.01 \mathrm{e}$ \\
\hline Tokat 4 & $104.46 \pm 0.02 \mathrm{c}$ & $40.72 \pm 0.10 \mathrm{a}$ & $26.13 \pm 0.01 \mathrm{c}$ & $15.09 \pm 0.12 b$ & $1.77 \pm 0.02 \mathrm{c}$ \\
\hline 1310 & $14.94 \pm 0.13 \mathrm{~g}$ & $41.27 \pm 0.17 \mathrm{a}$ & $17.21 \pm 0.08 \mathrm{~g}$ & $8.53 \pm 0.04 \mathrm{e}$ & $0.90 \pm 0.00 \mathrm{e}$ \\
\hline
\end{tabular}

${ }^{*}$ : Difference between means represented with the different letter in the same column is significant at 0.05 level.

\section{Antioxidant activity}

As shown in Table 4, differences were observed between cultivars and genotype in terms of total antioxidant capacity (TEAC) $(\mathrm{p}<0.05)$. Accordingly; the highest total antioxidant capacity was determined to be $41.29 \mu \mathrm{molTE} / \mathrm{g}$ in 'Rovada' cultivar; whereas, the lowest total antioxidant capacity was $33.11 \mu \mathrm{molTE} / \mathrm{g}$ in 'Tokat 2' cultivar (Table 4). In a study examining some berry fruit species, total antioxidant activity of black and red currants was measured as 51.6 and $24.6 \mu \mathrm{mol}$ of $\mathrm{Fe} 2+/ \mathrm{g}$, respectively (Borges et al., 2010).

\section{Sugars}

In this study, contents of glucose, fructose, and sucrose among basic sugars in currant fruits were determined and differences between cultivars and genotype in terms of these sugar contents were revealed (Table 4). Sucrose content was measured to be lower than other sugars. Additionally, the highest sucrose content was obtained as $2.21 \mathrm{~g} / \mathrm{kg}$ from 'S. Nigrum' cultivar. While the highest value of glucose content was obtained to be $34.23 \mathrm{~g} / \mathrm{kg}$ in 'S. Nigrum' cultivar, the lowest value was $17.21 \mathrm{~g} / \mathrm{kg}$ in genotype 1310 . The highest fructose value was measured as $16.23 \mathrm{~g} / \mathrm{kg}$ in 'Red Lake' cultivar. Zheng et al. (2009) evaluated amounts of glucose, fructose, and sucrose in currant fruits and they determined the amount of fructose and glucose between $38.7-45.7 \mathrm{~g} / \mathrm{L}$ and 31.1-43.8 g/L. Milivojevic et al. (2012) worked on black and red currants and they found that black cultivars had fructose content between $16.4-40.9$ and $18.3-34.2 \mathrm{~g} / \mathrm{kg}$, and white cultivars had fructose content between 30.3-40.2 and 20.8-26.0 g/kg; glucose content between 21.4-78.9 and $14.4-24.9 \mathrm{~g} / \mathrm{kg}$ in black cultivars, and between $44.3-86.8$ and $16.8-24.5 \mathrm{~g} / \mathrm{kg}$ in white cultivars; sucrose content was between $1.8-4.1$ and $1.0-7.8 \mathrm{~g} / \mathrm{kg}$ in black cultivars and between $1.5-1.7$ and $0.5-1.8 \mathrm{~g} / \mathrm{kg}$ in white cultivars, respectively.

\section{Conclusions}

In this study, currants were grown under the same ecologic conditions and same cultural applications, thus genetic base had an effect on biochemical contents of fruits and these differences were statistically significant $(p<0.05)$. In the study, standard currant cultivars and the genotype were observed to be rich in phenolic compound particularly chlorogenic acid, catechin, rutin, ellagic acid and protocatechuic having anti-carcinogenic, anti-fungal, and antimicrobial properties. In addition, it will be beneficial to consider the genotype 1310 having superior traits in biochemical content and coming to the fore especially in terms of catechin, caffeic acid, ferulic acid, malic acid, and total antioxidant capacity which important for breeding 
386

new cultivars. Results obtained from the present study are thought to be a source for further research and to have importance in terms of revealing the actual value of world's germplasms.

\section{References}

Abraham G, FlechasJ (1992). Management of fibromyalgia: rationale for the use of magnesium and malic acid.Journal of Nutritional Medicine 3:4959.

AlpS, Ercisil S, Dogan H, Temim E, Leto A,Zia-Ul-Haq M, Hadziabulic A, Aladag H (2016). Chemical composition and antioxidant activity Ziziphora clinopodioides ecotypes from Turkey. Romanian Biotechnological Letters 21(2):11298-11303.

Anttonen MJ, Karjalainen RO (2006). High-performance liquid chromatography analysis of black currant (Ribes nigrum L.) fruit phenolics grown either conventionally or organically. Journal of Agricultural and Food Chemistry 54:7530-7538.

Bevilacqua AE, Califano AN (1989). Determination of organic acids in dairy products by high performance liquid chromatography. Journal of Food Science 54:1076-1079.

Borges G, Degeneve A, Mullen W, Crozier A (2010). Identification of flavonoid and phenolic antioxidants in black currants, blueberries, raspberries, red currants, and cranberries. Journal of Agricultural and Food Chemistry 58:3901-3909.

Celik A, Ercisil S, Turgut N (2007). Some physical, pomological and nutritional properties of kiwifuit cv. Hayward. International Journal of Food Science and Nutrition 58:411-418.

Cemeroglu B (2007). Food analysis. Food Technology Society Publication, No.34. Ankara, Turkey pp 168-171.

Dogan H,ErcisiS, Temim E, Hadziabulic A, Tosun M, YilmazSO,Zia-UlHaq M (2014). Diversity of chemical content and biological activity in flower buds of a wide number of wild grown caper (Capparis ovate Desf.) genotypes from Turkey. Comptes Rendus De L Academie Bulgare Des Sciences 67(11):1593-1600.

Ercisli S, Sayinci B, Kara M, Yildiz C, Ozturk I (2012).Determination of size and shape features of walnut (Juglans regia $\mathrm{L}$ ) c cultivars using image processing. Scientia Horticulturae 133:47-55.

Eyduran SP, Agaoglu YS (2007).Some pomological and plant characteristics of currant varieties cultivated in Ankara (Ayaş) condition. Tarim Bilimleri Dergisi 13(3):293-298.

Gavrilova V, Kajdzanoska M, Gjamovski V, Stefova M (2011). Separation, characterization and quantification of phenolic compounds in blueberries and red and black currants by HPLC-DAD-ESI-MS. Journal of Agricultural and Food Chemistry 59:40094018.

Hakkinen S, Heinonen M, Karenlampi S, Mykkanen H, Ruuskanen J, Törrönen R (1999). Screening of selected flavonoids and phenolic acids in 19 berries. Food Research International 32:345-353.

Haslam E (1996). Natural polyphenols (vegetable tannins) as drugs: possible modes of action. Journal Natural Products 59(2):205-215.

Hegedus A, Engel R, Abranko L, Balogh E, Blazovics A, Herman R, HalaszJ, Ercisli S, Pedryc A, Stefanovits-Banyai E (2010). Antioxidant and antiradical capacities in apricot (Prunus armeniaca L.) fruits: Variations from genotypes, years, and analytical methods. Journal of Food Science
75(9)::722-730.

Heim KE, Tagiaferro AR, Bobilya DJ (2002). Flavonoid antioxidants: chemistry, metabolism and structure-activity relationships. The Journal of Nutritional Biochemistry 13(10):572-584.

Kamiloglu O, Ercisli S, Sengul M, Toplu C, Serce S (2009). Total phenolics and antioxidant activity of jujube (Zizyphus jujube Mill.) genotypes selected from Turkey. African Journal of Biotechnology 8(2):303-307.

Karacali I (2012). The storage and marketing of horticultural crops. Ege University, Agricultural Faculty, No: 494, Izmir, Turkey (in Turkish).

Maatta K, Kamal-Eldin A, Törrönen R (2001). Phenolic compounds in berries of black, red, green, and white currants (Ribes sp.). Antioxidants and Redox Signaling3(6):981-993.

Maatta-Riihinen KR, Kamal-Eldin A, Matrila PH, Gonzalez-Paramas AM, Törrönen R (2004).Distribution and contents of phenolic compounds in eighteen Scandinavian berry species. Journal of Agricultural and Food Chemistry 52:44774486.

Melgarejo P, Salazar DM, Artes F (2000). Organic acids and sugars composition of harvested pomegranate fruits. European Food Research and Technology 211:185-190.

Mikulic-Petkovsek M, Rescic J, Schmitzer V, Stampar F, Slatnar A, Koron $\mathrm{D}$, Veberic $\mathrm{R}$ (2015). Changes in fruit quality parameters of four Ribes species duringripening. Food Chemistry 173:363-374.

Mikulic-Petkovsek M, Koron D, Veberic R (2016). Quality parameters of currant berries from three different cluster positions. Scientia Horticulturae 210:188-196.

Milivojevic J, Slatnar A, Mikulic-Petkovsek M, Stampar F, Nikolic M, Veberic $R$ (2012). The influence of early yield on the accumulation of major taste and health-related compounds in black and red currant cultivars (Ribes spp.). Journal of Agricultural and Food Chemistry 60:2682-2691.

Moyer R, Hummer K, Wrolstad RE, Finn C (2002). Antioxidant compounds in diverse Ribes and Rubus germplasm. Acta Horticulturae 585:501-505.

Netzel M, Strass G, Kaul C, Bitschb I, Dietrich H, Bitsch R (2002). In vivo antioxidative capacity of a composite berry juice. Food Research International 35:213-216.

Ozgen M, Reese RN, Tulio AZ, Scheerens JC, Miller AR (2006). Modified 2,2-Azino-bis-3-ethylbenzothiazoline-6-sulfonic Acid (ABTS) method to measure antioxidant capacity of selected small fruits and a comparison to Ferric Reducing Antioxidant Power (FRAP) and 2,2-Diphenyl-1picrylhdrazyl (DPPH) methods. Journal of Agricultural and Food Chemistry 54:1151-1157.

Parr AJ, Bolwell GP (2000). Phenols in the plant and in man. The potential for possible nutritional enhancement of the diet by modifying the phenols content or profile. Journal of the Science of Food and Agriculture 80:985-1012.

Penniston KL, Steele TH, Nakada SY (2007). Lemonade therapy increases urinary citrate and urine volumes in recurrent calcium oxalate stone formers. Urology 70(5):856-860.

Rodriguez-Delgado MA, Malovana S, Perez JP, Borges T, GarciaMontelongo FJ (2001). Separation of phenolic compounds by highperformance liquid chromatography with absorbance and fluorimetric detection.Journal of Chromatography A 912:249-257. 
Tosun M, Ercisi S, Karlidag H, Sengul M (2009). Characterization of red raspberry (Rubus idaeus L.) genotypes for their physicochemical properties.Journal of Food Science 74(7):C575-C579.

Wojdylo A, OszmianskiJ, Milczarek M, WietrzykJ (2013).Phenolic profile, antioxidant and antiproliferative activity of black and red currants (Ribes spp.) from organic and conventional cultivation. International Journal of Food Science and Technology 48:715-726.

Wu X, Beecher GR, Holden JM, Haytowitz DB, Gebhardt SE, Prior RL (2004). Lipophilic and hydrophilic antioxidant capacities of common foods in the United States. Journal of Agricultural and Food Chemistry 52(12):4026-4037.

Yazici K, Sahin A (2016). Characterization of pomegranate (Punica granatum L.) hybrids and their potential use in further breeding. Turkish Journal of Agriculture and Forestry 40:813-824.

ZhengJ, Kallio H, Yang B (2009). Effects of latitude and weather conditions on sugars, fruit acids and ascorbic acid in currant (Ribes sp.) cultivars. Journal of the Science of Food and Agriculture 89:2011-2023.
ZhengJ, Yang B, Ruusunen V, Laaksonen O, Tahvonen R, Hellsten J, Kallio $\mathrm{H}$ (2012). Compositional differences of phenolic compounds between black currant $($ Ribes nigrum $\mathrm{L}$.) cultivars and their response to latitude and weather conditions. Journal of the Agricultural and Food Chemistry 60:6581-6593.

Zhishen J, Mengcheng T, Jianming W (1999). The determination of flavonoid contents in mulberry and their scavenging effects on superoxide radicals. Food Chemistry 64:555-559.

Zorenc Z, Veberic R, Stampar F, Koron D, Mikulic-Petkovsek M (2016). Changes in berry quality of northern highbush blueberry (Vacinium corymbosum L.) during the harvest season. Turkish Journal of Agriculture and Forestry 40:855-864. 